fore the force is certainly central, and if it differs at all from the law of Newton, the deviation must be relatively unimportant."

The orbit is also remarkable for its great eccentricity, which surpasses that of any known stellar orbit.

For many years to come the angular motion will be very slow, and Dr. See draws attention to the fact that observations of distance will be more valuable than angular measures in effecting a further improvement in the elements.

\section{THE THIRD INTERNATIONAL ZOOLOGICAL CONGRESS AT LEYDEN.}

FROM first to last this Congress, the Session of which lasted from September 15 to $2 \mathrm{I}$, was favoured by exceptionally fine autumn weather, and the quaint old town of Leyden, where the meeting was held, as well as the island of Marken, the Zoological Park at Graveland (where apteryx thrives and gnus are kept in free pastures), the Zoological Station at Helder, the sea-beach of Katwijk and Scheveningen, and the port of Rotterdam, to all of which places excursions were organised, were under these circumstances seen at their very best.

The character of the meeting was eminently international. The daily bulletin, although edited in French, contained announcements of lectures to be held and of papers to be read in English and in German, and in the Sections these three different tongues often succeeded one another rapidly and fraternally.

On the Sunday evening preceding the official opening there had been an informal mustering of the forces then already assembled, and Prof. Hubrecht, of Utrecht, who, as President of the Netherlands Zoological Society, gave a hearty welcome to those present, hinted at the inadvisability of allowing the use of more than these three languages.

Still, besides forty-two representatives from Great Britain and the United States, sixty-three from France and Belgium, and twenty from Germany and Austria, there were no less than eleren Russians, eight Scandinavians; and sixty-four Dutchmen in scribed as members, who had to restrict the use of their native language to conversation among themselves.

The total number of members inscribed was 232 , and not only the number but also the quality of the zoologists assembled was such as to make this international gathering really a very representative one, which served to bring together some of the veterans of the old guarl, and a great number of the younger generation of zoologists.

A glance along the list of those that were present will show this at once. There we find Jul. Vict. Carus, Th. Eimer, V. Hensen, A. Metzger, F. E. Schulze, R. Semon, J. W. Spengel, R. Virchow, Aug. Weismann, K. Grobben, Ch. Julin, E. de Sélys Longchamps, C. Littken, H. Field, O. C. Marsh, W. B. Scott, C. W. Stiles, R. Blanchard, E. Bouvier, A. Certes, A. Milne-Edwards, E. Perrier, L. Vaillant, J. Anderson, Sir W. H. Flower, S. J. Hickson, John Murray, Adam Sedgwick, R. B. Sharpe, R. Trimen, d'Arcy Thompson, S. Apathy, S. Brusina, C. Emery, R. Collett, A. Kowalevsky, W. Schimkevitch, W. Salensky, W. Blasius, N. Zograff, W. Leche, F. A. Smitt, Th. Studer, van Wÿhe, Max Weber, Vosmaer, Sluiter, van Rees, Lidth de Jeude, Kerbert Jentink, Hubrecht, Hoffmann, I loek, Horst, Everts, Buittikofer, M. C. Dekhuyzen, E. Rosenberg, and van Bemmelen. Very many of these read papers in the Sections, three of them (John Murray, A. Milne-Edwards and Weismann) addressed general meetings; whereas on the Tuesday evening a lecture on the curiosities of bird life, illustrated by coloured lantern-slides; was given by Dr. Bowdler Sharpe, of the British Museum, and was attended by the young Queen and the Queen-Regent.

The Committee of Organisation, to whose excellent arrangements much of the success of the meeting was due, were Prof. Hubrecht of Utrecht, Dr. Jentink, Director of the Natural IHistory Museum, Leyden (President of the Congress), Dr. Hoek (Secretary), and Dr. IIorst (Treasurer).

There were six different Sections, a new feature of which was the inclusion of palæontology with recent zoology. There was no separate Palæontological Section.

In the first Section (general zoology, geographical distribution, with the inclusion of fossil faunas and evolution theory), Mr. A. Sedgwick, of Cambridge, gave an exposition of his views concerning direct cellular continuity in the living organism. In a later meeting of the same Section, Prof. Apathy, of Klatusen- burg (Hungary), demonstrated a series of the most beautifuland delicate microscopical preparations, which, already at an earlier date, have led him to.conclusions very similar to those of Sedgwick just referred to.

Prof. Hensen, of Kiel, gave an interesting account of the Plankton expedition, its aims and its results.

Prof. Eimer, of Tuibingen, spoke in this Section on the subject of orthogenesis, and on the impotence of natural selection for the production of new species.

In the second and third Sections, devoted to living and extinct vertebrates, their anatomy and embryology, papers were read by Profs. Zograff of Moscow, Vaillant, O. C. Marsh, Biittikofer, Littken, Leche, Semon, Hubrecht, and van Bemmelen.

The fourth, fifth and sixth Sections embraced the invertebrates, one of them being specially devoted to entomology. Messrs. Wardell Stiles (from the United States), Hickson, Blanchard, Goto (from Tokyo), Perrier, Kowalevsky, Schimkevitch, Gilson, Salensky, and Julin were among the principal speakers in these Sections.

The sectional meeting which proved to be the most attractive was the one that was held on the last day of the meeting, when in the second Section, temporarily presided over by Rudolf Virchow, Dr. E. Dubois, the indefatigable naturalist, who has devoted the last six years to the collection of palæontological specimens in Sumatra and Java, gave a full account of the finding of the remnants of his Pithecanthropus erectus.

The four fragments (a femur, the upper part of a skull, and two teeth) upon which this new species, looked upon by its author as an intermediate stage between the anthropoids and man, was founded, were laid before the Section, together with a good many pieces intended for comparison. A most interesting discussion followed, in which Virchow, O. C. Marsh, Emil Rosenberg, Sir William Flower and Prof. Martin took a prominent part. Virchow's contention was that the four fragments did not belong to the same animal. He attempted to derive arguments from pathological anatomy, which would show that the osteophytic outgrowths of the femur described by Nubois were indications tending rather towards the human than towards the simian origin of the femur. Nevertheless, he spoke in a very appreciative tone, telling the Section that he had only wished to put in a point of interrogation where Dubois' affirmations did not appear to him to be as yet fully justified.

Prof. Marsh was inclined, on grounds derived from his vast experience in palæontological excavations, to support many of Dubois' conclusions. He had noticed exostoses of a similar nature as those of Pithecanthropus in fossil animals of quite different orders. He pointed out the necessity of carefully comparing these remains with those from the Sivalik Hills.

Prof. Rosenberg, considering more especially the femur and the cranium from the point of view of the anatomist, tried to show that the four characteristics, by which Dubois separates the femur of Pithecanthropus from that of man, are found also in human femora, in some few cases even all of them combined. The skull, on the contrary, is more that of a primate; but he did not agree with Dubois' argument that certain peculiarities of its plamm muchale tended to show that the animal had assumed a more erect gait. Very similar peculiarities are found in the New-World Cebus, which moves on all fours. Rosenberg acknowledged, however, that the high intrinsic value of the fragments was in no way diminished by the doubts expressed by him, because the femur, even if human, would prove Tertiary man to have existed in Java, the origin of man being thus pushed further back towards the earlier Tertiary period.

The results of this discussion, though not a decisive triumph for Pithecanthropus as a valid species, was a unanimous recognition of the great importance of Dr. Dubois' researches.

Another interesting afternoon lecture, which attracted numerous members of different Sections, was given by Prof. W. B. Scott, of Princeton, and was illustrated by lantern-slides. The wonderful continuity of the American tertiary formations, the vast geographical scale on which they are developed, and the excellent state of preservation of their fossils, was specially insisted upon. Skeletons of many members of the beantifully continuous phylogenetic series were projected on the screen.

Of the lectures held at the general meetings, those of Dr. John Murray and Prof. Milne-Edwards were most interesting to the audiences they addressed. Prof. Milne-Edwards spoke on the extinct avifauna of the Mascarene Islands in its relation to that of certain islands in the Pacific Ocean, and Dr. Murray gave an admirable survey of deep-sea exploration in general. 
and of its principal restlts. In seconding a vote of thanks to Dr. Murray, Prof. Milne-Edwards availed himself of the opportunity of complimenting him, in terms of the highest eulogy, on the completion of the Challenger Reports, the cost of which has been so liberally met by the British Government, and the editorship of which has been in the hands of Dr. Murray since the death of the late Sir Wyville Thomson.

Prof. Weismann's lecture to the general meeting treated of a much more abstruse and complicated subject, viz. Germinal Selection. Under this name he introduced what he holds to be a supplementary hypothesis to that of Natural Selection, and by which he explains the fact that useful variations appear to be protected from their very first appearance, so that, when natural selection would require them, they are indeed always there. The simultaneous development of harmonious variations of different parts of the same organism was at the same time elucidated on similar principles.

It may be noticed in passing, that these theoretical views of Weismann's approach very closely to views expressed as the result of quite different series of palæontological observations by W. B. Scott and others. It is clear that an explanation of certain groups of facts is yet wanted. Weismann will have to show that his speculations do indeed bridge this gap.

In the three general meetings other questions of international significance were settled. In the first one, presided over by the Minister of the Interior, Mr. van Houten, the prize to which the name of the present Emperor of Russia is attached was awarded to Dr. R. T. Scharff, of Dublin. In the second one, of Wednesday, September I9, the conclusions of a report of M. Bouvier, on the question of bibliographical reform, were unanimously carried, and seven members of the Controlling Commission nominated, viz. Messrs. Spengel, Sidney Hickson, W. B. Scott, Blanchard, Hoek, Schimkevitch, and Lang.

Another commission for the definite codification of the rules of zoological nomenclature was appointed, and consists of Messrs. Blanchard, Victor Carus, Jentink, Sclater, and Wardell Stiles.

In the final mecting, Sir William Flower was nominated to the presidency of the next Zoological Congress, in 1808 . Upon the proposition of the President of the Congress, in the name of the Committee of Organisation, it was decided to meet in England, the exact place of meeting being left to the consideration of the vermanent Bureau.

During the Congress, as has already been announced in NAture, three of its most eminent members-Messrs. Weismann, Milne-Edwards, and Sir Wm. Flower-received the honorary degree of Doctor in Science (Section of Zoology and Botany) from the Senate of the Utrecht University, upon the proposal of the Faculty of Natural Philosophy.

On Saturday the meeting closed, and the members united in a farewell banquet in the concert hall, where the Minister of the Interior was again present.

On Sunday, the 22nd, the Amsterdam Zoological Society Natura Artis Magistra invited the members to a luncheon party, and to a visit to its well-known gardens and aquarium.

After this the members of the Congress definitely separated. There is not one of them who has not extended the circle of his personal acquaintance amongst his fellow-workers in the field of zoology. And this extension of the feelings of international scientific fraternity is one of the great advantages of these cosmopolitan gatherings.

\section{THE INTERNATIONAL CONGRESS OF PHYSIOLOGISTS AT BERN.}

I.

MONDAY, September 9.- Presidents, Profs. Chauveau and Bowditch. Dr. Boruttau (Göttingen) demonstrated on a platinum wire contained in a glass tube filled with $\cdot 6$ per cent. salt solution, electrical changes (negative variation), analogous to those occurring upon stimulation of a nerve trunk. The negative variation occurred not only upon electrical, but also upon chemical and mechanical stimulation of the wire. The apparatus used for the purpose were a Hermann's repeating rheotome and a Thomson's galvanometer.

Profs. Ewald and Goltz (Strassburg) showed a dog from which they had removed, at three successive stages, large portions of the spinal cord. In all $158 \mathrm{~mm}$. had been removed; this involved all the spinal cord below the middle dorsal region, inclusive of the cauda equina. The dog had already survived the last operation two years. The condition was as follows :(I) Entire muscular degeneration of hind limbs, and back muscles below mid-dorsal region; (2) evacuation of freces, and sphincter ani ext., normal; (3) large quantities of urine collected in bladder, but were eventually evacuated; (4) vascular tone normal. Animal gave birth to young ones since last operation, and suckled them normally.

Prof. Fano (Florence) showed a special apparatus by which he could measure exactly motor reaction time. Ife worked on the dog, and found that it was 32.6 sec. for anterior paw, 27.32 for posterior. After removal of parts of cortical layer of frontal and occipital lobes this reaction time was diminished; upon stimulation of same regions it was increased. From this the author concluded that the cortical cells, especially of the frontal region, exert a constant inhibitory action on the spinal cord.

Prof. Langley (Cambridge) gave a demonstration on (I) the general anatomical relations of the sympathetic system; (2) connection of nerve cells and nerve fibres; (3) reflexes from the sympathetic system.

Dr. Mann (Edinburgh) rearl a paper, accompanied by lanternslides, and gave a demonstration on the position of the psychomotor areas in the rabbit, hedgehog, dog, and cat. The result of the author's rescarches was to show that (I) the same general scheme of arrangement of the psycho-motor areas holds good throughout the animal kingdom, and (2) that there exist in the above animals centres of varying psycho-motor value (higher and lower centres in the physiological sense).

Prof. Gaule (Ziirich) discussed the growth of muscle, and came to the conclusion that it was periodic, and that there exist in muscular fibres changes corresponding to these periods. $\mathrm{He}$ further discussed and showed the effect of excision of the inferior cervical ganglion upon the biceps and psoas of the same side. Within twenty-four hours of this excision these muscles increase in weight, and have their resistance to mechanical strain greatly diminished (rupture easily).

Prof. Vitzou (Bucharest) produced blindness in a monkey by removal of the occipital region of the brain; two years after the operation the animal recovered, to a slight extent, its sight. Unon examining the brain at the seat of the lcsion, he found a tissue of new formation ; this tissue was very vascular, and its extirpation reproduced the blindness. Histological examination of this tissue showed the presence of nervous elements, which the author regarded as of true new formation.

Dr. Demoor (Brussels) stained the brains of animals to which he had given a strong dose of morphine or chloral hydrate by Golgi's method. Demoor found that the plotoplasm of the cell processes in these animals presented a characteristic mannilliform aspect, which was not to be observed in normal animals. The author showed his preparations

Monday Afternoon.--Presidents, Prof. Hensen and Mosso.Prof. Herzen (Lausanne) described the characters of a gastric juice obtained by the author and Dr. Fremont (Vichy) from the isolated stomach of a dog. The osophagus was sutured to the duodenum, and a fistula was made, from which the gastric juice was collected. The juice was without smell or colour, was highly acid, and cotid digest its own weight of coagulated albumin. The author further gave the result of his researches on the influence of the spleen on pancreatic digestion. He found a given quantity of blood from the splenic vein, added to a pancreatic infusion, greatly increased its digestive power, whereas the same quantity of ordinary arterial blood did not.

Prof. Schiff (Geneva) discussed the effects of an isolated lesion of one pyramid, and showed that it produced degeneration in the pyramid only, and not in the pyramidal tract.

Dr. Giirber (Würzburg) described the results of his researches on the crystallisation of serum albumin. He treated horse serum after Hofmeister's method (ammonium sulphate), and obtained four kinds of crystals. The author showed diagrams of these, and gave the results of their analysis.

Prof. Tigerstedt (Stockholm) described a new apparatus, on the principle of Pettenkofer and Voit, for respiration experiments on man. The author's apparatus is of such volume as to be able to contain several men at the same time.

Tuesday Morning.-Presidents, Prof. Rutherford and Hegir. -Dr. His, junr. (Leipsig) supported Engelmann's view that the propagation of the rhythmic cardiac wave takes place from fibre to fibre. He could not confirm Kent's results. He found in mammals, including man, a single muscular bundle which showed cross striation, going from the inter-auricular down into

No. [353, vol. 52] 